\title{
INCREASED CHEMICAL STABILITY OF BACILLUS LICHENIFORMIS $\alpha$-AMYLASE UPON ACETYLATION
}

\author{
ADYANI AZIZAH ABD HALIM ${ }^{a, b *}$, HABSAH ABDUL KADIR ${ }^{b}$, \\ SAAD TAYYAB ${ }^{b}$
}

\begin{abstract}
Acetylated derivative (47\%) of Bacillus licheniformis $\alpha$-amylase (BLA) was prepared using acetic anhydride and its molecular properties including chemical stability were studied with the help of CD spectroscopy, analytical gel filtration and enzymatic activity measurements. Acetylated BLA preparation was found homogeneous with respect to charge and size based on electrophoretic and chromatographic results. Expansion in the molecular size of the modified BLA was evident from the decrease in its elution volume on Superdex 200 column as well as Stokes radius determination. Near-UV $C D$ spectra suggested significant change in the tertiary structure of the acetylated BLA, whereas secondary structures remained unaltered, as judged from the far-UV CD spectra. Acetylated BLA displayed greater chemical stability against urea denaturation as revealed by the increase in the mid-point $\left(\mathrm{C}_{\mathrm{m}}\right)$ of the denaturation curve and significant retention of biological activity at different urea concentrations. These results indicated greater conformational stability of acetylated BLA in the presence of urea.
\end{abstract}

Keywords: Bacillus licheniformis $\alpha$-amylase, acetylation, chemical stability, urea denaturation

\section{INTRODUCTION}

The native structure of a protein is generally stabilized by different noncovalent forces, which include hydrogen bonds, ionic, van der Waals and hydrophobic interactions [1, 2]. Any minor structural change in the protein

\footnotetext{
a Department of Oral and Craniofacial Sciences, Faculty of Dentistry, University of Malaya, 50603 Kuala Lumpur, Malaysia

b Biomolecular Research Group, Biochemistry Programme, Institute of Biological Sciences, Faculty of Science, University of Malaya, 50603 Kuala Lumpur, Malaysia

*Corresponding author: adyanihalim82@gmail.com
} 
molecule may affect its functions. Protein surface contributes significantly towards maintaining the native conformation of a protein through its interaction with the surrounding medium. The operational conditions of many industrial processes may lead to the exposure of proteins / enzymes to various environmental factors, such as $\mathrm{pH}$, temperature, pressure and solvent composition (salts, alkali and denaturants), which are known to disrupt the native protein conformation [3]. Therefore, increasing protein stability of various industrial enzymes has become an important issue in biotechnology in order to make the industrial processes economical.

Several factors contribute toward high thermostability of enzymes, which include electrostatic interactions, metal binding sites, core hydrophobicity, high packing density etc. Protein mutants (neutral) of charged amino acid residues or charged mutants of neutral amino acids have been found to exhibit either higher or lower stability [4,5]. For example, Miki et al. have reported destabilization of cytochrome $\mathrm{c}$ by partial charge neutralization [6]. On the other hand, replacement of two positively-charged residues (K139 and K207) in E. coli L-asparaginase with neutral and negative charge substitutions (K139A, K207A, K139D, K207D) has been shown to produce stable enzyme with greater resistance against heat compared to wild type [4]. A few ribonuclease Sa mutants such as Asp49 $\rightarrow$ His, Asp25 $\rightarrow$ Lys and Gly14 $\rightarrow$ Lys have shown greater stability than the wild type [5]. Enzymatic activities of thermolysin mutants, S53D and S65D have been found $78 \%$ and $68 \%$, respectively, higher than the wild type enzyme [7]. Chemical modification of lysine residues has also yielded negatively-charged enzymes with greater thermostability and enzymatic activity [8]. Different lysine-modified horseradish peroxidase preparations have shown greater stability in urea and dimethyl sulfoxide solutions as well as higher thermal stability [9, 10]. Lysinemodified papain has also shown increased catalytic activity and stability than native papain [11].

$\alpha$-Amylases form an important group of enzymes due to their use (starch hydrolysis) in the initial stages of various industrial processes [12]. Among various $\alpha$-amylases, Bacillus licheniformis $\alpha$-amylase (BLA) has remained the enzyme of choice in many industries due to its high thermostability [13]. It consists of 483 amino acid residues [14], distributed in the form of three domains, namely, 'A', 'B' and ' $C$ ' [15]. Domain ' $B$ ' is characterized by the presence of two calcium binding sites, while the third calcium binding site is located at the interface of domains ' $A$ ' and ' $C$ ' [16]. Presence of calcium at the binding sites of this enzyme contributes significantly toward stabilization of its structure and increased enzymatic activity [17-19]. A few salt bridges present in BLA are also believed to be responsible for high thermostability of the enzyme [16]. A previous report has shown production of highly negatively-charged variants of BLA through acetylation, which were found active, thermostable and more resistant towards irreversible inactivation [8]. However, data about the influence of 
acetylation on the conformational stability of BLA against urea is lacking. Here, we present our results on the production of acetylated BLA derivative with increased chemical stability.

\section{RESULTS AND DISCUSSION}

\section{Acetylation of BLA}

Modified amino groups in a protein are usually determined by TNBSA assay [20]. Any decrease in the color intensity at $335 \mathrm{~nm}$ of the yellowcolored trinitrophenyl derivatives formed from the reaction of TNBSA with the protein's amino groups indicates amino groups' modification. Figure 1 shows results of TNBSA color reaction obtained with native and acetylated (treated with 20 -fold molar excess of acetic anhydride) BLAs. Increase in the protein concentration for both native and acetylated BLAs produced a linear increase in the absorbance at $335 \mathrm{~nm}\left(\mathrm{Abs}_{335 \mathrm{~nm}}\right)$. However, acetylated BLA showed reduction in the slope value compared to the native BLA, indicating lesser intensity of the trinitrophenyl derivatives. This loss in the color yield suggested modification of the amino groups of BLA. The linear plots obtained with native and acetylated BLAs (Figure 1) obeyed the following straight line equations (1) and (2), respectively.

$$
\begin{aligned}
& \mathrm{Abs}_{335 \mathrm{~nm}}=2.29 \times \text { Amount of protein }(\mathrm{mg})+0.032 \\
& \mathrm{Abs}_{335 \mathrm{~nm}}=1.22 \times \text { Amount of protein }(\mathrm{mg})+0.035
\end{aligned}
$$

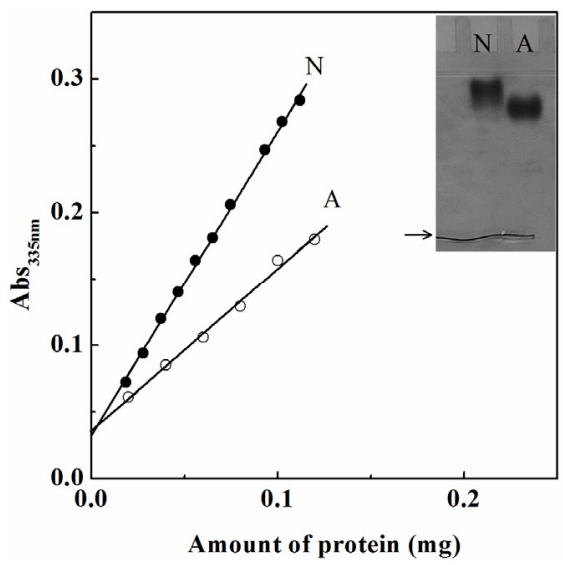

Figure 1. Determination of TNBSA color reaction of native, 'N' BLA $(\bullet)$ and acetylated, 'A' BLA $(O)$. The least squares analysis was used to draw the straight lines. Insert shows electrophoretogram of native, 'N' and acetylated,

'A' BLAs on $10 \%$ polyacrylamide gel. Arrow indicates the position of the bromophenol blue as a tracking dye marker. 
The percentage of modification in the acetylated BLA was found to be $\sim 47 \%$, as determined from the TNBSA plots of native and acetylated BLAs (Fig. 1). This yielded the number of the modified amino groups in $47 \%$ acetylated BLA as 14 based on the presence of $1 \alpha$-amino and $28 \varepsilon$-amino groups in BLA [16].

Electrophoretic results of the native and acetylated BLAs on $10 \%$ polyacrylamide gel showed charge homogeneity due to the presence of a single major band (inset of Fig. 1). However, acetylated BLA moved with higher relative mobility $(0.23)$ compared to 0.10 obtained with native BLA. Such increase in the relative mobility of acetylated BLA seems to be understandable as acetylation neutralized some of the positive charges in the protein [21]. These results agreed well with a previous report on carbamylation of BLA, where the modified protein showed higher mobility due to neutralization of positive charges of amino groups [22]. However, the value of relative mobility obtained with acetylated BLA was found lesser than that obtained with carbamylated BLA [22]. Since, carbamylated BLA had $81 \%$ modification, the net negative charge would have been higher than the acetylated BLA with $47 \%$ modification. The elution profiles of native and acetylated BLA preparations on a Superdex 200 column also showed a single symmetrical peak, which was suggestive of size homogeneity of these preparations (Fig. 2).

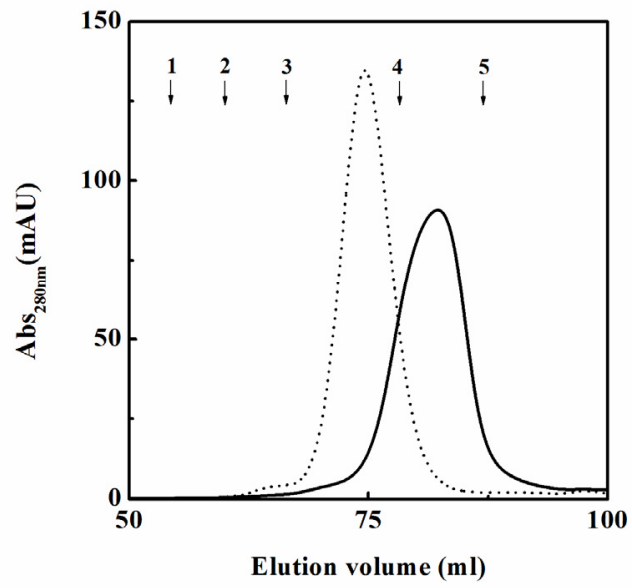

Figure 2. Elution profiles of native (-) and acetylated (…...) BLAs on Superdex 200 column $(0.8 \times 53.5 \mathrm{~cm})$ equilibrated with $20 \mathrm{mM}$ Tris- $\mathrm{HCl}$ buffer, $\mathrm{pH} 7.0$.

Protein samples $(2 \mathrm{mg} / \mathrm{mL})$ were injected through the injection valve and eluted at a flow rate of $0.5 \mathrm{~mL} / \mathrm{min}$. Arrows (1-5) indicate the position of different standard proteins: 1 . $\beta$-amylase; 2 . alcohol dehydrogenase;

3. BSA; 4. carbonic anhydrase and 5. myoglobin. 


\section{Conformational Changes in Acetylated BLA}

Stokes radii and CD spectral measurements were made to study conformational changes in BLA upon acetylation.

\section{Stokes Radii}

Stokes radii of native and acetylated BLAs were determined on a calibrated Superdex 200 column $(0.8 \times 53.5 \mathrm{~cm})$ in $20 \mathrm{mM}$ Tris-HCl buffer, $\mathrm{pH}$ 7.0. The elution profiles of native $(\mathrm{N})$ and acetylated $(\mathrm{A}) \mathrm{BLAs}$ are shown in Figure 2. The peak positions of various standard proteins viz. $\beta$-amylase, alcohol dehydrogenase, BSA, carbonic anhydrase and myoglobin on the same column are indicated by arrows $1-5$. The void volume and the inner volume of the column were found to be 40.66 and $110.38 \mathrm{~mL}$, respectively. Table 1 shows the values of the elution volume $\left(V_{e}\right)$ of different standard proteins along with native and acetylated BLAs. As shown in Figure 2 and Table 1, acetylated BLA eluted earlier $\left(\mathrm{V}_{\mathrm{e}}=74.71 \mathrm{~mL}\right)$ than the native BLA $\left(V_{e}=82.03 \mathrm{~mL}\right)$, suggesting increase in the hydrodynamic volume of the acetylated BLA [23, 24]. Further analysis of these elution profiles was made by transforming elution volumes of the native and acetylated BLAs as well as marker proteins into $K_{\mathrm{d}}$ and $K_{\mathrm{av}}$ values [25] (Table 1). These values were then treated according to the methods of Ackers [26] and Laurent and Killander [27] (columns 5 and 6 in Table 1). Linear plots obtained by these treatments (Figures $3 \mathrm{~A}$ and $\mathrm{B}$ ) followed equations (3) and (4), respectively.

$$
\begin{aligned}
& \text { Stokes radius }(\mathrm{nm})=7.06 \times \operatorname{erfc}^{-1} K_{d}-2.22 \\
& \left(-\log K_{\text {av }}\right)^{1 / 2}=0.11 \times \text { Stokes radius }(n m)+0.23
\end{aligned}
$$

Table 1. Analytical gel filtration data of various marker proteins, native and

\begin{tabular}{|c|c|c|c|c|c|c|}
\hline Proteins & $\operatorname{Ve}(\mathrm{mL})$ & $K_{d}$ & Kav & $\operatorname{erfc}^{-1} K_{d}$ & $\left(-\log K_{\mathrm{av}}\right)^{1 / 2}$ & Stokes radius $(\mathrm{nm})$ \\
\hline$\beta$-Amylase & 54.35 & 0.127 & 0.196 & 1.078 & 0.841 & 5.4 \\
\hline $\begin{array}{l}\text { Alcohol } \\
\text { dehydrogenase }\end{array}$ & 59.95 & 0.179 & 0.278 & 0.963 & 0.746 & 4.6 \\
\hline BSA & 66.34 & 0.239 & 0.368 & 0.833 & 0.659 & 3.6 \\
\hline $\begin{array}{l}\text { Carbonic } \\
\text { anhydrase }\end{array}$ & 78.26 & 0.349 & 0.539 & 0.665 & 0.518 & 2.4 \\
\hline
\end{tabular}
acetylated BLAs on Superdex 200 column $(0.8 \times 53.5 \mathrm{~cm})$ at pH 7.0. 


\begin{tabular}{|l|c|c|c|c|c|c|}
\hline Proteins & $V e(\mathrm{~mL})$ & $K_{\mathrm{d}}$ & $K_{\mathrm{av}}$ & $\mathrm{erfc}^{-1} K_{\mathrm{d}}$ & $\left(-\log K_{\mathrm{av}}\right)^{1 / 2}$ & Stokes radius $(\mathrm{nm})$ \\
\hline Myoglobin & 86.98 & 0.430 & 0.664 & 0.560 & 0.421 & 1.8 \\
\hline Native BLA & 82.03 & 0.384 & 0.593 & 0.617 & 0.476 & $\left.\begin{array}{l}2.13 \text { (Eq. 3) } \\
2.14 \text { (Eq. 4) }\end{array}\right] 2.13$ \\
\hline Acetylated BLA & 74.71 & 0.316 & 0.488 & 0.709 & 0.558 & $\left.\begin{array}{l}2.78 \text { (Eq. 3) } \\
2.86 \text { (Eq. 4) }\end{array}\right] 2.82$ \\
\hline
\end{tabular}
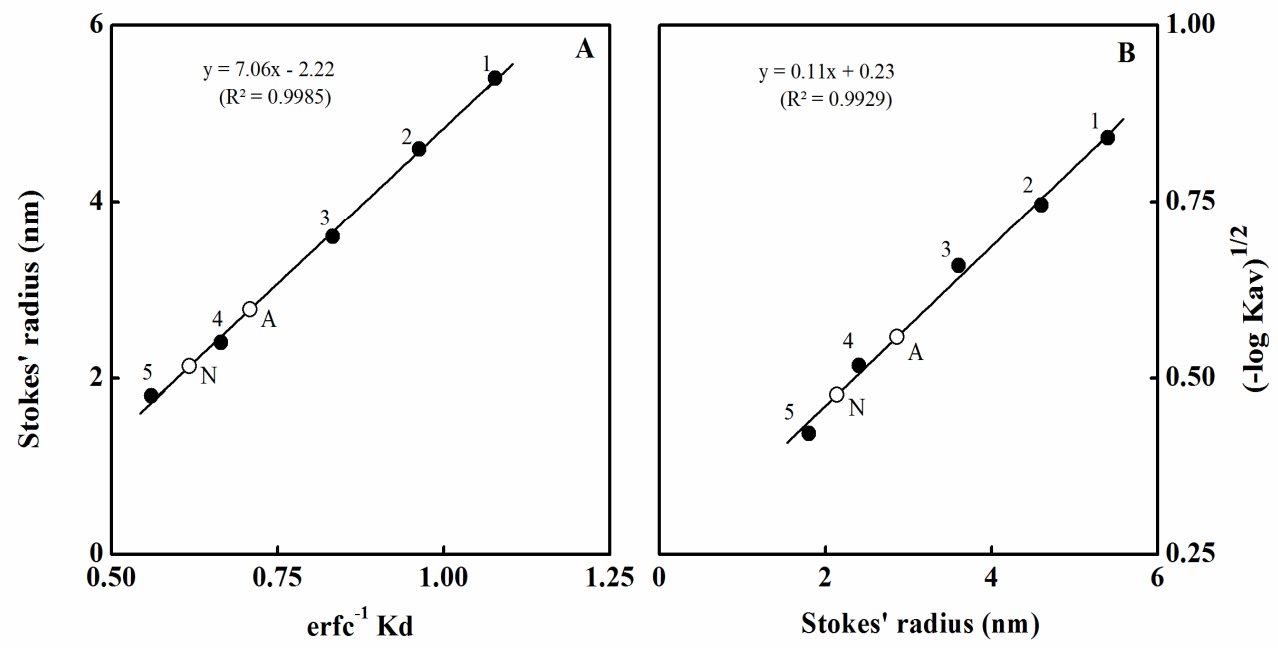

Figure 3. Stokes radii determination of native, ' $N$ ' and acetylated, ' $A$ ' BLAs according to the method of (A) Ackers [26] and (B) Laurent and Killander [27]. Numbers $1-5$ refer to various standard proteins as 1 . $\beta$-amylase; 2 . alcohol dehydrogenase; 3 . BSA; 4 . carbonic anhydrase and 5 . myoglobin. The least squares analysis was used to draw the straight lines.

Stokes radii of native and acetylated BLAs, obtained from equations (3) and (4) together with their mean values are listed in the last column of Table 1. The value of the Stokes radius of native BLA $(2.13 \mathrm{~nm})$, as determined by Superdex 200 gel filtration was found much smaller compared to the Stokes radius value $(3.20 \mathrm{~nm})$, obtained by dynamic light scattering [17]. Such a lower value of the Stokes radius can be ascribed to the interaction of the enzyme with various gel matrices [28]. Irrespective of this difference, acetylated BLA yielded a value of $2.82 \mathrm{~nm}$ for the Stokes radius (Table 1), which was higher than the Stokes radius of the native BLA, suggesting increase in the hydrodynamic volume of the enzyme. Several earlier reports have shown increase in the Stokes radius of a protein upon acetylation [29, 30]. Acetylation 
of amino groups increases the net negative charge on a protein by abolishing the positive charge on amino groups, which may be responsible for such increase in the hydrodynamic volume of the protein $[29,30]$.

\section{Far-UV and Near-UV CD Spectra}

The far-UV and the near-UV CD spectra were used to study the effect of acetylation on the secondary and tertiary structures of BLA, respectively. Occurrence of two minima at 208 and $222 \mathrm{~nm}$ in the far-UV CD spectrum of native BLA (Fig. 4A) suggested the presence of the $\alpha$-helical structure [31]. Acetylated BLA produced comparable CD spectrum (Fig. 4A), suggesting presence of similar secondary structures in the acetylated preparation. In a previous report, Shaw et al. have also shown superimposable far-UV CD spectra upon acetylation of 17 amino groups of BLA [8]. Nonetheless, significant alteration in the near-UV CD spectrum $(255-285 \mathrm{~nm})$ of the acetylated BLA was observed (Fig. 4B), indicating changes in the tertiary structure of BLA brought about by acetylation. This was in accordance to an earlier report on citraconylation of BLA, showing tertiary structural changes upon modification [31]. Since acetylation abolishes the positive charge on amino groups, changes in the protein's tertiary structure are expected due to alteration in the charge network of the native protein [31].

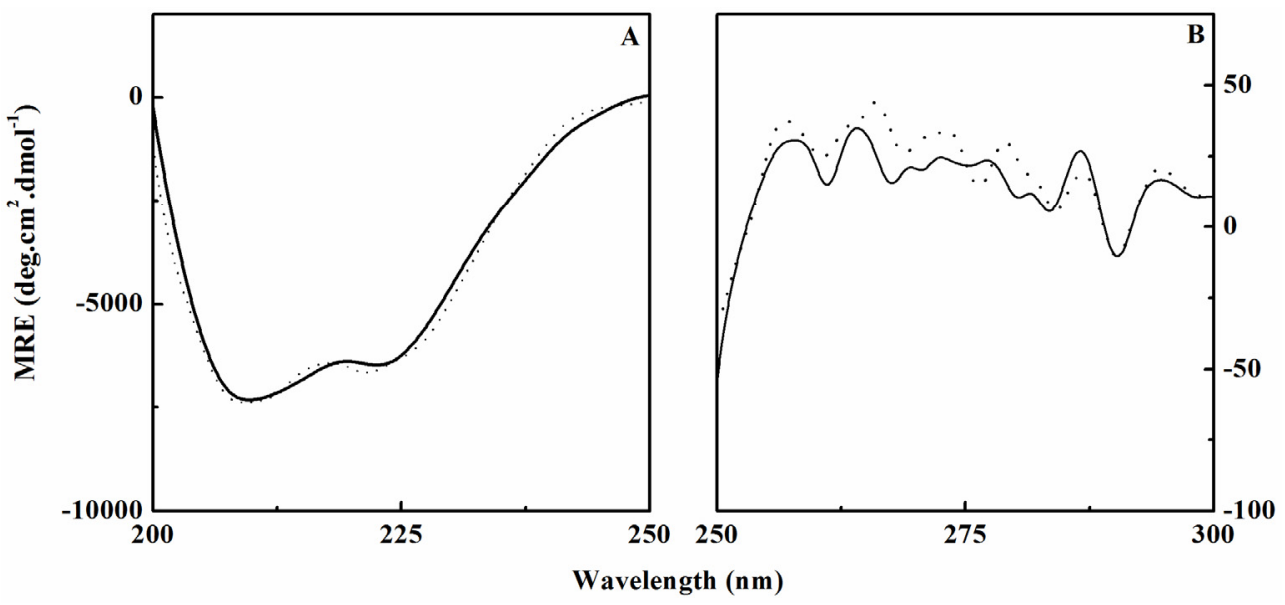

Figure 4. Far-UV CD (A) and near-UV CD (B) spectra of native $(-)$ and acetylated (.......) BLAs, obtained in $20 \mathrm{mM}$ Tris- $\mathrm{HCl}$ buffer, $\mathrm{pH} 7.0$ at $25^{\circ} \mathrm{C}$.

The protein concentration and cuvette path length were $1.8 \mu \mathrm{M} ; 1 \mathrm{~mm}$ and $9.1 \mu \mathrm{M}$; $10 \mathrm{~mm}$ for far-UV and near-UV CD spectral measurements, respectively. 


\section{Urea Denaturation}

Conformational stability of native and modified BLAs was investigated by urea denaturation studies [32]. CD spectral measurements $\left(\mathrm{MRE}_{222 \mathrm{~nm}}\right)$ were used to monitor urea-induced structural changes in the protein. $\mathrm{MRE}_{222 \mathrm{~nm}}$ values of the native and the modified BLAs, collected at various urea concentrations were converted into the fraction denatured, $F_{D}$ and plotted against urea concentration to yield a denaturation curve (Fig. 5A). As shown in the figure, both native and modified BLAs produced a single-step, two-state transition. Urea transition for native BLA commenced at $1.75 \mathrm{M}$ and sloped off at $\sim 5.5 \mathrm{M}$ with the mid-point $\left(\mathrm{C}_{\mathrm{m}}\right)$ occurring at $3.55 \mathrm{M}$ urea concentration (Fig. 5A). A previous study has shown the occurrence of these points at much higher urea concentrations [22] compared to those found in this study. Differential saturation of commercial BLA samples with bound calcium may account for such differences in the above values. Furthermore, use of different $\mathrm{pH}$ in the denaturation study may also contribute to this effect. Interestingly, the transition curve of the acetylated BLA showed a significant shift towards higher urea concentrations, suggesting higher chemical stability of the modified BLA compared to the native BLA. The values of the start-, the mid- and the end-points of the transition were obtained at 2.25, 4.0 and $6.5 \mathrm{M}$ urea, respectively (Fig. 5A). These results clearly suggested stabilization of the acetylated BLA against urea denaturation.

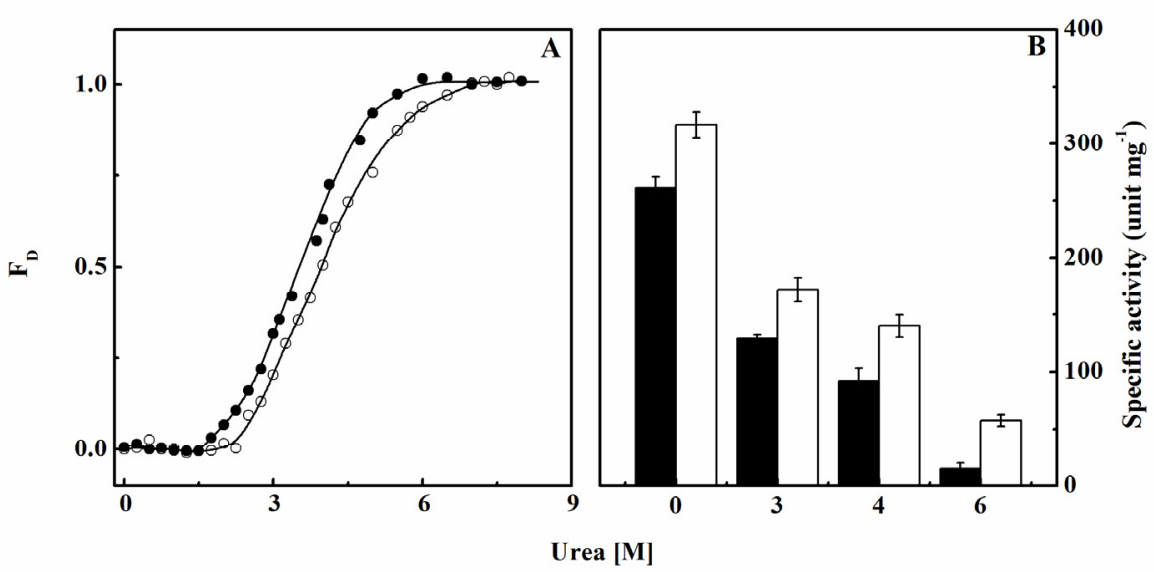

Figure 5. (A) Normalized transition curves of urea-induced structural changes in native $(\bullet)$ and acetylated $(O) B L A s$, as studied by $M_{R} E_{222 n m}$ measurements in $20 \mathrm{mM}$ Tris- $\mathrm{HCl}$ buffer, $\mathrm{pH} 7.0$ at $25^{\circ} \mathrm{C}$. (B) Effect of urea concentration on the specific activity of native $(\boldsymbol{\square})$ and acetylated $(\square)$ BLAs. 


\section{Enzymatic Activity}

The enzymatic activity of native and acetylated BLAs was checked both in the absence and the presence of different urea concentrations. Figure $5 B$ shows the effect of urea $(3,4$ and $6 \mathrm{M})$ on the enzymatic activity of native and acetylated BLAs. As evident from the figure, acetylated BLA produced a significantly higher $(21 \%)$ enzymatic activity compared to the native BLA in the absence of urea. In an earlier study, modified papain has been shown to exhibit significantly higher activity in buffer compared to its native counterpart [11]. About $54 \%$ and $44 \%$ enzymatic activity was retained in the acetylated $\mathrm{BLA}$ in the presence of 3.0 and $4.0 \mathrm{M}$ urea, respectively. These values were $32 \%$ and $52 \%$, respectively, higher than those obtained with the native BLA at these urea concentrations. Even at $6.0 \mathrm{M}$ urea, acetylated BLA showed $18 \%$ retention of the enzymatic activity compared to the $6 \%$ retention observed with the native BLA.

\section{CONCLUSIONS}

Taken together, acetylated BLA (with $47 \%$ modified amino groups) was found to be more stable and resistant against urea denaturation. Since acetylation of BLA altered the tertiary structure without changing secondary structures, it seems that alteration in the overall conformation induced by abolishment of positive charges on lysine residues might have increased hydrophobic interactions in the modified protein.

\section{EXPERIMENTAL SECTION}

\section{Materials}

Bacillus licheniformis a-amylase (BLA) (lot 018K7018V), alcohol dehydrogenase, $\beta$-amylase, bovine serum albumin (BSA), carbonic anhydrase, myoglobin, Superdex ${ }^{\circledR} 200$ (prep grade), blue dextran, 3,5-dinitrosalicyclic acid, starch from potatoes and urea (SigmaUltra) were supplied by Sigma-Aldrich Co., USA. Maltose was obtained from R \& M Chemicals, UK. Acetic anhydride was acquired from Riedel-de Haën, Germany. Tris base and 2,4,6trinitrobenzene sulfonic acid (TNBSA) were the products of Amresco, USA and Pierce Chemical Company, USA, respectively. Analytical grade samples of other chemicals were used. 


\section{Analytical Methods}

Protein estimations were made either by the method of Lowry et al [33] using BSA as the standard or spectrophotometrically on a Shimadzu double-beam spectrophotometer, model UV-2450 (Shimadzu, Kyoto, Japan), using a molar extinction coefficient of BLA as $139,690 \mathrm{M}^{-1} \mathrm{~cm}^{-1}$ at $280 \mathrm{~nm}$ [18]. The method of Pace and Scholtz was employed to determine the concentration of the stock urea solution [34].

\section{Polyacrylamide Gel Electrophoresis}

Electrophoresis of BLA was performed under non-denaturing conditions (without sodium dodecyl sulfate) on $10 \%$ polyacrylamide gel in $25 \mathrm{mM}$ Tris and $192 \mathrm{mM}$ glycine buffer, $\mathrm{pH}$ 8.3, following the method of Laemmli [35]. About $5 \mu \mathrm{g}$ protein in $7 \mu \mathrm{L}$ of the sample buffer was applied into each well and the electrophoresis was performed for $45 \mathrm{~min}$, using a current of $10 \mathrm{~mA}$ / well. Coomassie brilliant blue R-250 solution was used for gel staining as described earlier [35].

\section{Analytical Gel Filtration}

Stokes radii of native and acetylated BLAs were determined by analytical gel filtration [23]. A Superdex 200 column $(0.8 \times 53.5 \mathrm{~cm})$, equilibrated with $20 \mathrm{mM}$ Tris- $\mathrm{HCl}$ buffer, $\mathrm{pH} 7.0$ was used in ÄKTA avant 25 . Blue dextran and L-tyrosine were used to determine the void volume and inner volume of the column, respectively. Native and acetylated BLA samples as well as standard protein markers with known Stokes radii i.e. myoglobin $(1.8 \mathrm{~nm})$, carbonic anhydrase $(2.4 \mathrm{~nm})$, BSA $(3.6 \mathrm{~nm})$, alcohol dehydrogenase $(4.6 \mathrm{~nm})$ and $\beta$-amylase $(5.4 \mathrm{~nm})$ were also passed through the column. Each protein sample was passed at least 2-3 times to check the reproducibility of results. Normalization of the elution volume was made into distribution coefficient, $K_{d}$ and available distribution coefficient, $K_{a v}$ following the standard methods [25]. The data ( $K_{d}$ and $\left.K_{\mathrm{av}}\right)$ were then fitted according to the methods of Ackers [26] and Laurent and Killander [27] and the Stokes radii of native and acetylated BLAs were obtained from the linear equations of the above plots.

\section{Circular Dichroism Spectroscopy}

Any change in the secondary and tertiary structures of the acetylated BLA was studied by circular dichroism (CD) spectroscopy using Jasco spectropolarimeter, model J-815, equipped with a peltier type temperature controller (PTC-423S/15) attached to cell holder under constant nitrogen 
flow. Far-UV (200-250 nm) CD spectra were used to analyze changes in the secondary structure, while tertiary structural changes were monitored by near-UV (250-300 nm) CD spectra. The CD instrument was calibrated with $(+)-10$-camphorsulfonic acid. The protein sample $(1.8 \mu \mathrm{M})$ was taken in $1 \mathrm{~mm}$ path length cuvette for CD spectral measurement in the far-UV range, while $9.1 \mu \mathrm{M}$ sample was used in $10 \mathrm{~mm}$ path length cuvette for near-UV CD spectra. The scan speed and response time were fixed at $100 \mathrm{~nm} / \mathrm{min}$ and $1 \mathrm{~s}$, respectively, throughout the experiment. Each CD spectrum was taken as an average of three scans and CD spectra were corrected by subtracting the CD spectral contribution of the blank solutions from the CD spectra of the protein. The results were transformed into mean residue ellipticity (MRE) in deg. $\mathrm{cm}^{2} . \mathrm{dmol}{ }^{-1}$ following the procedure described earlier [36].

\section{Preparation of Acetylated BLA}

Acetylated BLA preparation was made according to the method suggested by Riordan and Vallee [37]. Using 20-fold molar excess of acetic anhydride over protein, aliquots of acetic anhydride were added slowly to 50 $\mathrm{mL}$ continuously stirred BLA solution $(10 \mathrm{mg} / \mathrm{mL})$, prepared in $0.1 \mathrm{M}$ sodium phosphate buffer, $\mathrm{pH} 7.4$ for about $30 \mathrm{~min}$ at $4^{\circ} \mathrm{C}$. The $\mathrm{pH}$ of the solution mixture was maintained at $\mathrm{pH} 7.4-7.8$ with the help of $1 \mathrm{~N}$ sodium hydroxide and stirring was continued until $\mathrm{pH}$ of the solution became constant. After completion of the reaction, the mixture was extensively dialyzed against 20 $\mathrm{mM}$ Tris- $\mathrm{HCl}$ buffer, $\mathrm{pH} 7.0$ with several changes. TNBSA reaction method was employed to determine the extent of the lysine modification [20]. The modified protein sample was also checked for possible modification of tyrosine residues by hydroxylamine treatment [38].

\section{Urea Denaturation}

Urea denaturation studies were made in the same way as described earlier [22]. All solutions used in these experiments were prepared in $20 \mathrm{mM}$ Tris- $\mathrm{HCl}$ buffer, $\mathrm{pH} 7.0$. To $0.5 \mathrm{~mL}$ protein solution, taken in different tubes, different volumes of the above buffer were added, followed by the addition of increasing volumes of the stock urea solution $(10.2 \mathrm{M})$ in order to achieve the desired urea concentration. The mixtures $(3.0 \mathrm{~mL})$ were incubated for $12 \mathrm{~h}$ at $25^{\circ} \mathrm{C}$ before $\mathrm{CD}$ spectral measurements. The values of MRE were converted into fraction denatured, $F_{D}$ [32] and plotted against urea concentration. The mid-point, $C_{m}$ values were obtained directly from the $F_{D}$ curve as the urea concentration corresponding to $0.5 \mathrm{~F}_{\mathrm{D}}$ value. 


\section{Enzymatic Activity}

Native and acetylated BLAs were submitted for enzymatic activity measurements both in the absence and presence of different urea concentrations $(3,4$ and $6 \mathrm{M})$ in $20 \mathrm{mM}$ Tris- $\mathrm{HCl}$ buffer, $\mathrm{pH} 7.0$ using potato starch (substrate), following the method of Bernfeld [39]. The enzymatic reaction was initiated by adding $0.4 \mathrm{~mL}$ of the activity buffer and $0.5 \mathrm{~mL}$ of the substrate solution ( $1 \%$ starch, w/v) to $0.1 \mathrm{~mL}$ of the stock enzyme solution $(0.72 \mu \mathrm{M})$. After $3 \mathrm{~min}$ incubation at $25^{\circ} \mathrm{C}$, the reaction was stopped by adding $1.0 \mathrm{~mL}$ of $1 \%(\mathrm{w} / \mathrm{v}) 3,5$-dinitrosalicylic acid and the tubes were kept in the boiling water bath for $5 \mathrm{~min}$. The mixture was diluted by adding $10 \mathrm{~mL}$ of water into these tubes upon cooling to room temperature. The absorbance of the colored solution was measured at $540 \mathrm{~nm}$ against a suitable blank. The concentration of reducing sugars was determined from the maltose standard curve. The specific activity of the enzyme was calculated following the procedure described elsewhere [36]. All solutions used for enzymatic activity measurement in the presence of different urea concentrations contained the desired urea concentration. The protein samples were first incubated with different urea concentrations for $12 \mathrm{~h}$ at $25^{\circ} \mathrm{C}$ before enzymatic activity measurements.

\section{ACKNOWLEDGEMENTS}

This project was financed by University of Malaya Research Grant (RG16011AFR) and Postgraduate Research Fund (PV018/2011B). S.T. is a member of the CRYSTAL research group. A.A.A.H. also acknowledges the UM scholarship. We thank the Dean, Faculty of Science and the Head, Institute of Biological Sciences for providing all necessary facilities and working atmosphere to carry out this work.

\section{REFERENCES}

1. C.N. Pace, B.A. Shirley, M. McNutt, K. Gajiwala, Federation of American Societies for Experimental Biology, 1993, 10, 75.

2. K.A. Dill, Biochemistry, 1990, 29, 7133.

3. V.I. Padma, A. Laxmi, Process Biochemistry, 2008, 43, 1019.

4. J. Vidya, M.V. Ushasree, A. Pandey, Enzyme Microbial Technology, 2014, 56, 15.

5. G.R. Grimsley, K.L. Shaw, L.R. Fee, R.W. Alston, B.M. Huyghues-Despointes, R. L. Thurlkill, J. M. Scholtz, C. N. Pace. Protein Science, 1999, 8, 1843. 
6. Y. Miki, K. Kakuyama, K. Soda, Biosystems, 1997, 44, 69.

7. T. Takita, T. Aono, H. Sakurama, T. Itoh, T. Wada, M. Minoda, K. Yasukawa, K. Inouye, Biochimica et Biophysica Acta, 2008, 1784, 481.

8. B.F. Shaw, G.F. Schneider, B. Bilgiçer, G.K. Kaufman, J.M. Neveu, W.S. Lane, J.P. Whitelegge, G.M. Whitesides, Protein Science, 2008, 17, 1446.

9. L. Hassani, R. Nourozi, Applied Biochemistry and Biotechnology, 2014, 172, 3558.

10. N.N. Ugarova, G.D. Rozhkova, I.V. Berezin, Biochimica et Biophysica Acta, 1979, 570, 31.

11. A. Szabó, M. Kotormán, I. Laczkó, L.M. Simona, Process Biochemistry, 2009, 44, 199.

12. R. Gupta, P. Gigras, H. Mohapatra, V.K. Goswami, B. Chauhan, Process Biochemistry, 2003, 38, 1599.

13. N. Declerck, M. Machius, P. Joyet, G. Wiegand, R. Huber R, C. Gaillardin, Biologia, 2002, 57, 203.

14. T. Yuuki, T. Nomura, H. Tezuka, A. Tsuboi, H. Yamagat, N. Tsukagoshi, S. Udaka, The Journal of Biochemistry, 1985, 98, 1147.

15. M. Machius, G. Wiegand, R. Huber, Journal of Molecular Biology, 1995, 246, 545.

16. N. Declerck, M. Machius, G. Wiegand, R. Huber, C. Gaillardin, Journal of Molecular Biology, 2000, 301, 1041.

17. J. Fitter, S. Haber-Pohlmeier, Biochemistry, 2004, 43, 9589.

18. A.R. Nazmi, T. Reinisch, H-J. Hinz, Journal of Thermal Analysis and Calorimetry, 2008, 91, 141.

19. A. Kumari, T. Rosenkranz, A. M. Kayastha, J. Fitter, Biophysical Chemistry, 2010, 151, 54.

20. A.F.S.A. Habeeb, Analytical Biochemistry, 1966, 14, 328.

21. M.M. Gote, M.I. Khan, J.M. Khire, Enzyme Microbial Technology, 2007, 40, 1312.

22. C.Y. Tan, R.N.Z. Raja Abdul Rahman, H.A. Kadir, S. Tayyab, Acta Biochimica Polonica, 2011, 58, 405.

23. H.N. Ong, B. Arumugam, S. Tayyab, The Journal of Biochemistry, 2009, 146, 895.

24. S.A. Datta, C.H. Mohan Rao, The Journal of Biological Chemistry, 2000, 275, 41001.

25. S. Tayyab, S. Qamar, M. Islam, Biochemical Education, 1991, 19, 149.

26. G.K. Ackers, The Journal of Biological Chemistry, 1967, 242, 3237.

27. T.C. Laurent, J. Killander, Journal of Chromatography A, 1964, 14, 317.

28. J.E. Kruger, D.R. Lineback, "Enzymes and their role in the cereal technology", AACC, Minnesota, 1987, 117.

29. A.A. Ansari, S.A. Kidwai, A. Salahuddin, The Journal of Biological Chemistry, 1975, 250, 1625.

30. S. Tayyab, S.K. Haq, Sabeeha, M.A. Aziz, M.M. Khan, S. Muzammil, International Journal of Biological Macromolecules, 1999, 26, 173. 
31. K. Khajeh, B. Ranjbar, H. Naderi-Manesh, A.E. Habibi, M. Nemat-Gorgani, Biochimica et Biophysica Acta, 2001, 1548, 229.

32. Y.H. Wong, H.A. Kadir, S. Tayyab, The Scientific World Journal, 2013, Article ID: 981902.

33. O.H. Lowry, N.J. Rosebrough, A.L. Farr, R.J. Randall, The Journal of Biological Chemistry, 1951, 193, 265.

34. C.N. Pace, J.M. Scholtz, "Protein structure. A practical approach", Oxford University Press, New York, 1997, 299.

35. U.K. Laemmli, Nature, 1970, 227, 680.

36. C.Y. Tan, R.N.Z. Raja Abdul Rahman, H.A. Kadir, S. Tayyab, African Journal of Biotechnology, 2010, 46, 7934.

37. J.F. Riordan, B.L. Vallee, Methods in Enzymology, 1967, 11, 565.

38. J.F. Riordan, B.L. Vallee, Methods in Enzymology, 1967, 11, 570.

39. P. Bernfeld, Advances in Enzymology, 1951, 12, 379. 